\title{
Distribution of repC plasmid-replication sequences among plasmids and isolates of Rhizobium leguminosarum bv. viciae from field populations
}

\author{
Lionel Rigottier-Gois, ${ }^{1}$ Sarah L. Turner, ${ }^{2}$ J. Peter W. Young ${ }^{2}$ \\ and Noëlle Amarger ${ }^{1}$
}

\author{
Author for correspondence: Noëlle Amarger. Tel: +33 3806330 92. Fax: +33 380633224 . \\ e-mail: amarger@dijon.inra.fr
}

1 Laboratoire de

Microbiologie des Sols, Institut National de la Recherche Agronomique, 17 rue Sully, BV 1540, 21034 Dijon cedex, France

2 Department of Biology, University of York, PO Box 373, York YO1 5YW, UK

\begin{abstract}
The distribution of four classes of related plasmid replication genes (repC) within three field populations of Rhizobium leguminosarum in France, Germany and the UK was investigated using RFLP, PCR-RFLP and plasmid profile analysis. The results suggest that the four repC classes are compatible: when two or more different repC sequences are present in a strain they are usually associated with different plasmids. Furthermore, classical incompatibility studies in which a Tn5-labelled plasmid with a group IV repC sequence was transferred into field isolates by conjugation demonstrated that group IV sequences are incompatible with each other, but compatible with the other repC groups. This supports the idea that the different repC groups represent different incompatibility groups. The same field isolates were also screened for chromosomal (plac12) and symbiotic gene (nodD-F region) variation. Comparison of these and the plasmid data suggest that plasmid transfer does occur within field populations of $R$. leguminosarum but that certain plasmid-chromosome combinations are favoured.
\end{abstract}

Keywords: Rhizobium leguminosarum bv. viciae, plasmids, repC, compatibility, natural populations

\section{INTRODUCTION}

The soil bacterium Rhizobium leguminosarum forms nitrogen-fixing nodules on the roots of several temperate leguminous plants. Most of the genes required for symbiotic function are carried on a large plasmid, the symbiotic plasmid or pSym (Johnston et al., 1978; Prakash et al., 1981). According to the host-specificity genes present on this plasmid the species has been divided into three biovars, bv. phaseoli, trifolii and viciae (Jordan, 1984). Most $R$. leguminosarum strains also carry between one and seven additional plasmids varying in size from 40 to $900 \mathrm{~kb}$. These plasmids are usually referred to as cryptic, i.e. of no known function, although several studies have demonstrated that they have physiological roles in free-living and/or symbiotic R. leguminosarum: for exopolysaccharide (Skorupska et al., 1991) and melanin (Hynes et al., 1988) production, carbon source utilization (Baldani et al., 1992) and symbiotic characteristics such as level of nitrogen fixation (Thurman et al., 1985; Hynes \& McGregor, 1990; Selbitschka \& Lotz, 1991). The plasmid component of the genome is usually stably maintained through successive generations, although occasional loss of part or all of a plasmid may occur during laboratory culturing and/or storage. Self-transmissible pSym and cryptic plasmids have been described (Johnston et al., 1978; Brewin et al., 1980); plasmid transfers are frequently associated with plasmid losses or rearrangements (Djordjevic, 1982; Soberon-Chavez, 1991; Brom et al., 1991; Geniaux \& Amarger, 1993). Moreover, studies of $R$. leguminosarum field populations provide indirect evidence that pSym transfer occurs in the environment (Young \& Wexler, 1988; Laguerre et al., 1992). The high plasticity of the plasmid component of the genome observed in laboratory studies is, therefore, likely to represent a natural phenomenon.

The aim of the current survey was to investigate this natural level of plasmid plasticity, with the longer-term 
Table 1. $R$. leguminosarum bv. viciae strains and plasmids used

\begin{tabular}{|c|c|c|}
\hline Strain/plasmid & Characteristics* & Reference/source \\
\hline \multicolumn{3}{|l|}{ R. leguminosarum bv, viciae } \\
\hline $\begin{array}{l}\text { BA5, BA7, BA9, BA11, BA12, BA19, BB2, BB4, BB12, } \\
\text { BB18, BB19, BB20, BC1, BC11, BD3, BD12, BD13, } \\
\text { BD15, SA1, SA2, SA6, SA10, SA20, SB19, SC1, SC3, } \\
\text { SC8, SC12, SC14, SD1, SD2, SD11, SD13, SD19, SD20 }\end{array}$ & $\begin{array}{l}\text { Field isolates from Bretennières, } \\
\text { France }\end{array}$ & INRA, Dijon \\
\hline $\begin{array}{l}\text { FIII-12, FIII-36, FIII-37, FIII-50, FIII-61, FIII-70, } \\
\text { FIII-71, FIII-72 }\end{array}$ & $\begin{array}{l}\text { Field isolates from Schlüterhof, } \\
\text { Germany }\end{array}$ & W. Lotz, Erlangen, Germany \\
\hline $\begin{array}{l}\text { RES-1, RES-2, RES-3, RES-4, RES-5, RES-6, RES-7, } \\
\text { RES-8, RES-9, RES-10 }\end{array}$ & Field isolates from Harpenden, UK & P. R. Hirsch, Rothamsted, UK \\
\hline P262SpSt & $\begin{array}{l}\text { Field isolate which had spontaneously } \\
\text { lost its } \mathrm{pSym} ; \mathrm{Sm}^{\mathrm{r}} \mathrm{Sp}^{\mathrm{r}}\end{array}$ & Geniaux \& Amarger (1993) \\
\hline $248,306,309$ & Field isolates & Hirsch et al. (1980) \\
\hline 1062/pRL1JI, 1062/pRL3JI, 1062/pRL4JI & Transconjugant strains & Hirsch et al. (1980) \\
\hline RSM2004 & 248 with pRL1JI: :cxd; $\mathrm{Km}^{\mathrm{r}}$ & Hirsch \& Spokes (1994) \\
\hline \multicolumn{3}{|l|}{ Plasmids } \\
\hline plac12 & $\begin{array}{l}26.2 \mathrm{~kb} \text { fragment containing the lac } \\
\text { region of } R . l \text {. bv. viciae } \mathrm{B} 155 \text { cloned } \\
\text { into pLAFR } 1\end{array}$ & Young \& Wexler (1988) \\
\hline pIJ1246 & $\begin{array}{l}6.6 \mathrm{~kb} \text { EcoRI fragment carrying nod } \\
\text { EFDABC genes of pRL1JI of } R . l . \mathrm{bv} \text {. } \\
\text { viciae } 248 \text { cloned into pSUP202; Ap } \\
\mathrm{Tc}^{\mathrm{r}}\end{array}$ & Downie et al. (1985) \\
\hline pGEM-T & $\mathrm{Ap}^{\mathrm{r}}$, lacZ & Promega \\
\hline pCT0370I & $\begin{array}{l}750 \text { bp of repC group I of plasmid } \\
\text { pBA7b of } R \text {. l. bv. viciae strain BA7 } \\
\text { cloned into pGEM-T; Ap }\end{array}$ & Turner et al. (1996) \\
\hline pCT0370II & $\begin{array}{l}750 \text { bp of repC group II of plasmid } \\
\text { pBA11b of } R . l \text {. bv. viciae strain } \\
\text { BA11 cloned into pGEM-T; Ap }\end{array}$ & Turner et al. (1996) \\
\hline pCT0370III & $\begin{array}{l}750 \text { bp of repC group III of plasmid } \\
\text { pSD13a of } R . l \text {. bv. viciae strain } \\
\text { SD13 cloned into pGEM-T; } \text { Ap }^{r}\end{array}$ & Turner et al. (1996) \\
\hline pCT0370IV & $\begin{array}{l}750 \text { bp of repC group IV of plasmid } \\
\text { pSD11a of } R . l . \text { bv. viciae SD11 } \\
\text { strain cloned into pT7-Blue-T vector; } \\
A^{r}\end{array}$ & Turner et al. (1996) \\
\hline
\end{tabular}

${ }^{*}$ R. l., Rhizobium leguminosarum; $\mathrm{Ap}^{\mathrm{r}}, \mathrm{Km}^{\mathrm{r}}, \mathrm{Sm}^{\mathrm{r}}, \mathrm{Sp}^{\mathrm{r}}, \mathrm{Tc}^{\mathrm{r}}$, resistance to ampicillin, kanamycin, streptomycin, spectinomycin and tetracycline, respectively.

aim of assessing the potential for and frequency of plasmid transfer within $R$. leguminosarum field populations. Previously such studies have been restricted due to an absence of markers for the majority of plasmids; indeed they were largely confined to pSym. We have recently described homologues of the plasmid replication gene repC and determined their distribution in three field populations of $R$. leguminosarum bv. viciae (Turner et al., 1996). As part of this work PCR primers were designed that specifically amplify sequences belonging to each of the four major groups (I-IV) of repC identified. In this study these primers and their products have been used to assess the distribution of such sequences within three $R$. leguminosarum populations, their distribution within the plasmid component of the genome and the relationship of $\operatorname{rep} C$ sequence variation to plasmid compatibility.

\section{METHODS}

Bacterial strains, plasmids and culture conditions. The strains used in this study are listed in Table 1 . They were isolates of $R$. leguminosarum bv. viciae recovered from root nodules of Pisum sativum grown at three field sites: Bretennières in France, Schlüterhof in Germany and Harpenden in the UK. Diversity within the French and German populations had been analysed previously by determining plasmid profile patterns for French isolates and ERIC-PCR fingerprints for German isolates (L. Rigottier-Gois \& W. Lotz, unpublished data). From the 136 isolates sampled in Bretennières, 35 isolates belonging to 18 distinct plasmid profiles were chosen. The 
eight isolates from Germany represented each of the distinct ERIC-PCR fingerprints identified within the 72 isolates analysed. The ten isolates from the UK were selected randomly from within the population of Harpenden. The plasmids used in this study are listed in Table 1. pCTO370I-IV each contain a $750 \mathrm{bp}$ product corresponding to one of the four repC groups (I-IV respectively) defined by Turner et al. (1996). $R$. leguminosarum strains were maintained on Bergersen's agar medium (Bergersen, 1961) supplemented with $0.02 \%$ yeast extract and were cultivated in TY (Beringer, 1974) at $28^{\circ} \mathrm{C}$ for DNA preparations. Escherichia coli DH5 $\alpha$ derivatives containing the pCTO370I-IV plasmids were grown at $37^{\circ} \mathrm{C}$ in LB (Sambrook et al., 1989) supplemented with ampicillin $\left(100 \mu \mathrm{g} \mathrm{ml}^{-1}\right)$.

Conjugation experiments. Patch matings and transconjugant screening for symbiotic proficiency were done as described by Geniaux \& Amarger (1993). Filter matings were carried out by depositing overnight TY cultures $(1 \mathrm{ml})$ of donor and recipient onto $24 \mathrm{~mm}$ diameter cellulose nitrate membrane filters (Millipore, pore size $0.45 \mu \mathrm{m}$, type $\mathrm{HA}$ ) and by incubating bacteria side up for $12 \mathrm{~h}$ at $28^{\circ} \mathrm{C}$. The filters were mixed in $10 \mathrm{ml}$ MilliQ sterile water, and after dilution the cell suspension was spread on appropriately amended TY plates $(\mathrm{Sm}$, streptomycin $200 \mu \mathrm{g} \mathrm{ml}^{-1}$; Km, kanamycin $50 \mu \mathrm{g} \mathrm{ml}^{-1}$ ). Transconjugants were purified and checked for the loss of indigenous repC group III or group IV plasmids by probing blots of Eckhardt gels with pCT0370III or pCT0370IV.

DNA methods. Plasmid profiles were obtained by agarose gel electrophoresis as described by Eckhardt (1978) and modified by Wheatcroft et al. (1990). Plasmid DNA for probes was isolated from $15 \mathrm{~h}$ E. coli cultures using the QIAGEN Plasmid Midi Kit, according to the manufacturer's instructions. DNA purification and restriction with EcoRI, electrophoresis, blotting, probe labelling and hybridization were performed as described by Laguerre $e t$ al. (1992), except that the membrane used was Nytran-N (Schleicher \& Schuell) and that chemiluminescence detection of digoxigenin-labelled DNA (Boehringer Mannheim) was used. The blots were hybridized successively with two probes following the protocol supplied by the manufacturer. Conditions for PCR amplifications using RSM2004-specific primers ( $5^{\prime}$ TCA AAC CAG GTA AGG CGA CG $3^{\prime}$ and $5^{\prime}$ ATT GAA TTC ACG TCA CTA AG $3^{\prime}$ ) were the same as those described for group-specific amplification by Turner $e t$ al. (1996). The products were sequenced using the Dye Terminator Cycle Sequencing kit (Perkin Elmer) and an $\mathrm{ABI} 377$ automated sequencer, according to the manufacturer's instructions. RES-6 group II PCR products were cloned into pGEM-T prior to sequencing, which was carried out using the plasmid as template and primers SP6 and $\mathrm{T} 7$, according to the manufacturer's instructions.

Products for restriction analysis of the group I and group II repC sequences were obtained by PCR amplification using the general primers RC1/RC3 and the conditions described by Turner et al. (1996). When group III- and IV-specific primers were used the conditions for PCR were: $1.5 \mathrm{mM} \mathrm{MgCl}$, $20 \mu \mathrm{M}$ dNTPs, $0 \cdot 1 \mu \mathrm{M}$ of each primer and $1 \mathrm{U}$ Taq polymerase (Appligene) per $100 \mu \mathrm{l}$ reaction, and the amplification programme was: $95^{\circ} \mathrm{C}$ for $3 \mathrm{~min}$, followed by 35 cycles of $94^{\circ} \mathrm{C}$ for $1 \mathrm{~min}, 59^{\circ} \mathrm{C}$ (group III) or $58^{\circ} \mathrm{C}$ (group IV) for $1 \mathrm{~min}$, $72{ }^{\circ} \mathrm{C}$ for $2 \mathrm{~min}$; the last cycle was followed by a final extension step of $3 \mathrm{~min}$. The PCR products $(8 \mu \mathrm{l})$ were digested with $10 \mathrm{U}$ restriction endonucleases in $10 \mu \mathrm{l}$ reaction volumes according to the manufacturer's recommendations. The following restriction endonucleases were used: $A l u \mathrm{I}, \mathrm{CfoI}, D d e \mathrm{I}$, HaeIII, MspI, NdeII and RsaI (Appligene). Similarities be- tween the restriction profiles of pairs of repC sequences were estimated from the proportion of shared restriction fragments to the total number of restriction fragments identified in all strains examined by using a simple matching coefficient (Sokal \& Michener, 1958). A dendrogram was constructed from the similarity matrix using the unweighted pair group method with arithmetic mean (UPGMA) (Sneath \& Sokal, 1973). HaeIII analysis of PCR-amplified nodD-F regions was performed according to Laguerre et al. (1996).

\section{RESULTS AND DISCUSSION}

\section{Background genetic diversity of the isolates}

Table 2 summarizes the results obtained when chromosomal diversity, symbiotic gene diversity and plasmid content were examined in 53 field isolates of $R$. leguminosarum. Chromosomal diversity was investigated by probing Southern blots of EcoRI-restricted genomic DNA with plac12 (Laguerre et al., 1992). Six classes were identified ( $a, i, n, o, p, q)$. Variation within the symbiotic genes of the isolates was investigated by RFLP analysis of PCR-amplified nodD-F gene fragments (Laguerre et al., 1996): eight distinct HaeIII restriction patterns were obtained (A, B, C, D, G, J, M, N).

The four most common nodD-F patterns (A, D, G, C) were each found associated with several different chromosomal backgrounds, for example nodD-F pattern A was associated with chromosomal backgrounds a3, i1, i5, i6, o and p. Similar patterns have been observed previously (Schofield et al., 1987, Young \& Wexler, 1988, Demezas et al., 1991; Laguerre et al., 1992), and these have been used to infer that pSym exchange does occur within field populations. When combined, the chromosomal and nodD-F data define 24 different chromosomal/nodD-F associations. Some of these associations were common to strains from more than one site. For example the associations between plac 12 type i 3 and nod-type J or between plac 12 type is and nod-type D are found in both French and German isolates, BB4 and FIII-50, BD13 and FIII-36 (Table 2). Such findings suggest that certain associations of $R$. leguminosarum host and symbiotic plasmids are particularly stable and have been maintained independently within the distinct populations.

The plasmid profile of each isolate was assessed initially using Eckhardt gel electrophoresis (Eckhardt, 1978). A typical gel is shown in Fig. 1(a). Plasmid profiles were obtained for 51 of the 53 isolates; unambiguous plasmid patterns could not be resolved for isolates FIII-12 and RES-1. The 51 isolates each contained between two and seven distinct plasmid bands and there were 31 different plasmid profiles (Table 2, Fig. 2). Prolonged laboratory culture resulted in the loss of a plasmid from a minority of isolates. This was the case for some isolates with profiles 7 or 15 which after laboratory cultures showed modified profiles $7^{\prime}$ and $15^{\prime}$ (Fig. 2). Isolates SC14, BA9 (modified profile shown, $7^{\prime}$ ) and FIII-71 (unmodified profile shown, 7) all lost their third smallest plasmid band and isolates SC8 and BD15 (modified profiles 
Table 2. Chromosomal diversity, symbiotic gene diversity, plasmid content and diversity of rep $C$ hybridizing sequences in field isolates of $R$. leguminosarum bv. viciae

\begin{tabular}{|c|c|c|c|c|c|c|c|}
\hline \multirow[t]{2}{*}{ Strains } & \multirow[t]{2}{*}{$\begin{array}{l}\text { plac12 } \\
\text { type }\end{array}$} & \multirow[t]{2}{*}{$\begin{array}{l}\text { nod } \\
\text { type }\end{array}$} & \multirow[t]{2}{*}{$\begin{array}{l}\text { Plasmid } \\
\text { type* }\end{array}$} & \multicolumn{4}{|c|}{$\begin{array}{l}\text { Size }(\mathbf{k b}) \text { of } E c o R I \text { restriction } \\
\text { fragment hybridizing with: }\end{array}$} \\
\hline & & & & $\operatorname{rep} C I$ & $\operatorname{rep} C \mathrm{II}$ & repCIII & repCIV \\
\hline BA7, BB19, BD12, SA2 & $\mathrm{i} 4$ & $\mathrm{D}$ & 1 & 7 & $14,9 \cdot 8$ & $1 \cdot 2$ & 8 \\
\hline SD1 & i5 & A & 2 & $4 \cdot 4$ & - & $1 \cdot 2$ & 8 \\
\hline BD13 & i5 & $\mathrm{D}$ & 3 & $4 \cdot 4$ & $14,9 \cdot 8$ & $1 \cdot 2$ & $4 \cdot 5$ \\
\hline BA12, SC1, SB19 & i4 & $\mathrm{D}$ & 4 & 14 & - & $1 \cdot 2$ & $8 \cdot 6$ \\
\hline BB2 & i1 & $\mathrm{D}$ & 5 & - & - & $1 \cdot 2$ & 8 \\
\hline BA11, BA19, BC11, SD19 & i3 & $\mathrm{D}$ & 6 & - & $14,9 \cdot 8$ & $1 \cdot 2$ & 8 \\
\hline BB20, SA6, FIII-71 & $\mathrm{i} 3$ & $\mathrm{D}$ & 7 & $8 \cdot 2$ & $14,9 \cdot 8$ & $1 \cdot 2$ & 8 \\
\hline BA9, SC14 & $\mathrm{i} 3$ & $\mathrm{D}$ & $7^{\prime}$ & $8 \cdot 2$ & - & $1 \cdot 2$ & 8 \\
\hline BB4 & $i 3$ & $\mathrm{~J}$ & 8 & - & - & $1 \cdot 2$ & 8 \\
\hline SA1 & i1 & A & 9 & - & - & $1 \cdot 2$ & 8 \\
\hline BB12 & i1 & G & 10 & - & - & $1 \cdot 2$ & - \\
\hline BB18 & i1 & G & 11 & - & - & $1 \cdot 2$ & 8 \\
\hline SD13 & i1 & A & 12 & - & - & $1 \cdot 2$ & 8 \\
\hline SD11 & i6 & A & 13 & - & - & $1 \cdot 2$ & $4 \cdot 5$ \\
\hline SC12 & i5 & G & 14 & - & - & $1 \cdot 2$ & - \\
\hline BA5, SD2 & i4 & $\mathrm{D}$ & 15 & - & $14,9 \cdot 8$ & $1 \cdot 2$ & $4 \cdot 5$ \\
\hline BD15, SC8 & i4 & $\mathrm{D}$ & $15^{\prime}$ & - & - & $1 \cdot 2$ & $4 \cdot 5$ \\
\hline SA20, RES-3 & a3 & G & 16 & - & - & - & - \\
\hline SC3 & a3 & A & 17 & - & - & - & 11 \\
\hline BC1, SA10, SD20 & a1 & $\mathrm{D}$ & 18 & $4 \cdot 4$ & $14,9 \cdot 8$ & - & $8 \cdot 6$ \\
\hline BD3 & a1 & D & 18 & 12 & $14,9 \cdot 8$ & - & $8 \cdot 6$ \\
\hline FIII-12 & o & A & No & - & - & 1.5 & 8 \\
\hline FIII-70 & $\mathrm{p}$ & A & 19 & 7 & 14 & $1 \cdot 2$ & 8 \\
\hline FIII-72 & $\mathrm{i} 2$ & $\mathrm{D}$ & 20 & 7 & 14 & $1 \cdot 2$ & 8 \\
\hline FIII-36, FIII-61 & i5 & $\mathrm{D}$ & 21 & 14 & - & $1 \cdot 2$ & $8 \cdot 6$ \\
\hline FIII-50 & i3 & $\mathrm{J}$ & 22 & - & $14,9 \cdot 8$ & $1 \cdot 2$ & 8 \\
\hline FIII-37 & a3 & M & 23 & 7 & 14 & - & 8 \\
\hline RES-1 & $\mathrm{q}$ & $\mathrm{C}$ & No & - & - & $1 \cdot 2$ & - \\
\hline RES-9 & $\mathrm{q}$ & G & 24 & - & - & $1 \cdot 2$ & - \\
\hline RES-2 & $\mathrm{n} 1$ & B & 25 & - & - & $1 \cdot 2$ & - \\
\hline RES-4 & $\mathrm{n} 1$ & $\mathrm{C}$ & 26 & - & - & $1 \cdot 2$ & - \\
\hline RES-7 & $\mathrm{n} 2$ & $\mathrm{C}$ & 27 & - & - & $2 \cdot 8$ & - \\
\hline RES-8 & $\mathrm{n} 1$ & $\mathrm{C}$ & 28 & - & - & $1 \cdot 2$ & - \\
\hline RES-5 & a3 & D & 29 & $5 \cdot 8$ & - & - & $8 \cdot 6$ \\
\hline RES-6 & a3 & $\mathrm{N}$ & 30 & $5 \cdot 8$ & $14,7 \cdot 7$ & - & - \\
\hline RES-10 & a3 & $\mathrm{D}$ & 31 & - & - & - & 8 \\
\hline
\end{tabular}

No, Not obtained.

* $7^{\prime}$ and $15^{\prime}$ correspond to modified profiles 7 and 15 observed after prolonged laboratory culture of isolates.

shown, 15') lost their smallest plasmid bands. Plasmid loss from isolate SC14 was observed independently in both the Dijon and York laboratories; the other plasmid losses were only documented at Dijon (BA9, SC8, BD15) or York (FIII-71). In all instances this corresponded to loss of a group II repC sequence in PCR analyses.

Several different isolates from the same field site shared identical plasmid profiles, for example French strains BA7, BB19, BD12 and SA2 or German isolates FIII-36 and FIII-61. More occasionally isolates from different field sites shared the same plasmid profile: the German isolate FIII-71 shared plasmid profile 7 with French isolates SA6 and BB20.

Of the three methods used to assess genetic diversity, plasmid profiles revealed the greatest level of variation between isolates. Strains with identical (e.g. BA7, BB19, BD12, SA2) or very similar plasmid profiles (e.g. profiles 6 and 7) share plac12 and nodD-F patterns, but isolates with identical plac12 and nodD-F patterns do not always share the same plasmid profile. For example 
(a)

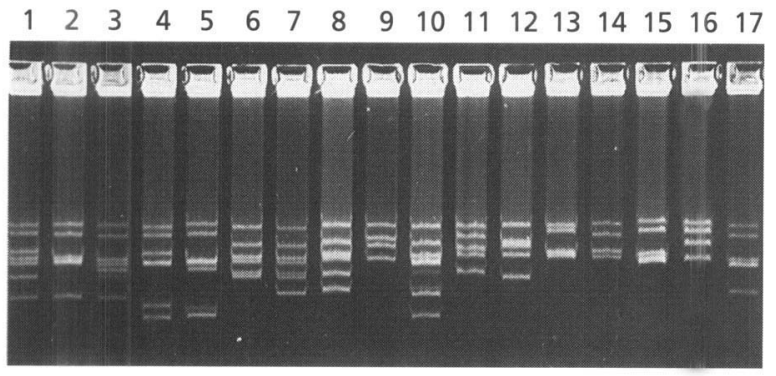

(b)
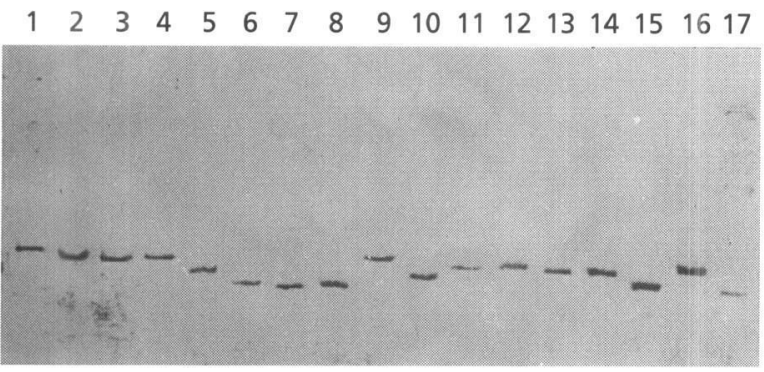

Fig. 1. (a) Agarose gel electrophoresis of plasmids of Rhizobium isolates. (b) Southern blot of the same gel hybridized to the repCIII probe. Lanes: 1, BA7; 2, SD1; 3, BD13; 4, BA12; 5, BB2; 6, BA11; 7, SA6; 8, SC14; 9, BB4; 10, SA1; 11, BB12; 12, BB18; 13, SD13; 14 , SD $11 ; 15$, BA5; 16, SC12; 17, BA5.

isolates with plac12 pattern i4 and nodD-F pattern D have a number of different plasmid profiles (profiles 1, 4, $15,15^{\prime}$ ) (Table 2). These strains must be closely related in their chromosome and symbiotic gene organization but have apparently lost or gained plasmids and/or undergone plasmid rearrangements, again supporting a high level of plasticity within the plasmid component of $R$. leguminosarum field populations. On the basis of this characterization of plac12 patterns, nodD-F patterns and plasmid profiles, the 53 isolates can be grouped into 35 different genotypes (Table 2).

\section{Plasmid distribution and diversity: repC amplification}

Turner et al. (1996) used PCR to isolate and partially sequence plasmid replication $(r e p C)$ sequences from 22 $R$. leguminosarum field isolates (some of which were included in the present study). The results of our earlier study suggest that there are at least four distinct but related groups of repC sequence (I-IV). The partial sequence data obtained for the 22 PCR-amplified repC sequences showed that the divergence between sequences clustered in the same group was less than $3 \%$ for groups I and II but was as much as $15 \%$ for groups III and IV. To see if these levels were representative of the divergence found in a greater sample of isolates, RFLP analysis of repC PCR products of the 37 French isolates was undertaken; the results are summarized in Fig. 3.
When repC sequences belonging to several different groups were present within one isolate, the use of the general RC1 and RC3 primer sequences led to amplification of repC group I and II sequences, where these were present either singly or jointly. There were no restriction polymorphisms associated with either the group I or the group II amplification products, which is consistent with the low level of sequence variation found in these groups (Turner et al., 1996). Amplification of the $\operatorname{rep} C$ group III sequences using the general primer pair only occurred if both group I and II sequences were absent, and amplification of group IV sequences was restricted to isolates BB18 and SD11. This reinforces the conclusion of Turner et al. (1996) that some repC sequences may match the general primers more closely, and be amplified more efficiently than others.

The group III- and IV-specific PCR primers were used to amplify these sequences for RFLP analysis. All of the 32 group IV amplification products had identical restriction profiles to SD11, except BB18 (Fig. 3). The group III amplification products were much more polymorphic. Five different restriction profiles were obtained. Three of these patterns correspond to distinct sequences within the group III cluster of the phylogenetic trees of Turner et al. (1996). Furthermore, the restriction fragment variation (Fig. 3) is in accordance with the observations of these authors, since the group III PCR-RFLP results imply a greater level of sequence variation than do the group I and II results.

\section{Plasmid distribution and diversity: repC hybridization}

Southern blots of EcoRI-digested total genomic DNAs from all 53 field isolates used for the plac12 analysis were probed sequentially with the four repC probes. Each probe hybridized to some but not all of the 53 isolates. All isolates except two hybridized with at least one of the probes, and ten isolates hybridized with all four probes. Isolates with the same genetic background (plac12, nodD-F and plasmid profile) always hybridized to the same combination of repC probes. The different hybridization patterns obtained with each probe are summarized in Table 2 and illustrated in Fig. 4. At least two different hybridization patterns were obtained with each probe. The group III hybridization patterns were the least polymorphic, all isolates except two hybridizing with a fragment of $1.2 \mathrm{~kb}$; and the group I hybridization patterns were the most polymorphic, six fragments being recognized ranging in size from 4.4 to $14 \mathrm{~kb}$ (Fig. 4).

The group I and III repC probe sequences have EcoRI sites at positions 682 and 570 respectively, and these are conserved in the equivalent amplification products from the field isolates (not shown). An EcoRI digest of genomic DNA would, therefore, be predicted to generate two hybridizing fragments, but only a single fragment was observed in each case. There is a conserved EcoRI site in the reverse primer RC3 (Turner et al., 1996); if this were conserved in the group I and III sequences then fragments of approximately 70 and $180 \mathrm{bp}$ respectively 

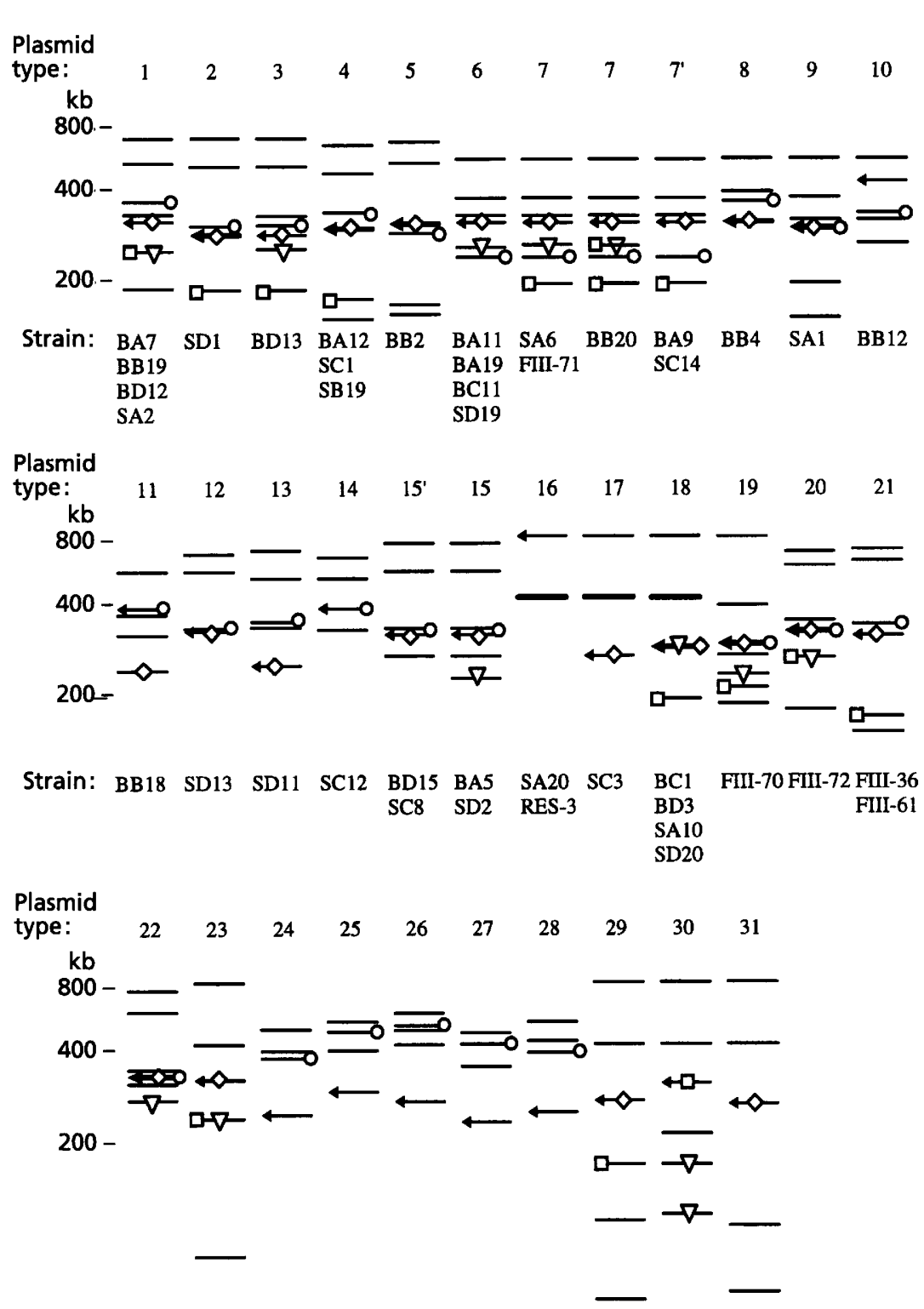

Strain: FIII-50 FIII-37 RES-9 RES-2 RES-4 RES-7 RES-8 RES-5 RES-6 RES-10

Fig. 2. Schematic representation of the different plasmid profiles listed in Table 2 and of the hybridization patterns obtained with each of the five probes tested: nod probe plJ1246 $(\leftarrow)$, repC probe $(\square \longrightarrow)$, repCll probe; $(-\nabla-)$, repClll probe $(-0)$, repCIV probe $(-\diamond-)$. ponding to possible plasmid doublet. $7^{\prime}$ and $15^{\prime}$ represent modified profiles 7 and 15 observed after prolonged laboratory culture of isolates. would be generated after EcoRI digestion. These fragments would have run off the gel and would not have been detected in the hybridization studies.

The conserved internal EcoRI sites of the group I and group III amplified sequences mean that the polymorphisms seen must be associated with sequences upstream of repC. If rep $A B$ sequences lie immediately upstream of $r e p C$, as they do in the six fully sequenced replicators (Nishiguchi et al., 1987; Tabata et al., 1989; Turner \& Young, 1995; Freiberg et al., 1997; RamirezRomero et al., 1997; Bartosik et al., 1995; GenBank accession number U60522), the polymorphic sites seen with the group I probe would be predicted to lie in sequences upstream of $r e p A$, since the hybridizing fragments are all $4.4 \mathrm{~kb}$ or larger, while those of group III would lie within $r e p A$ or $r e p B$. The significantly lower frequency at which polymorphisms were detected with the group III probe compared with the group I probe may reflect sequence constraints imposed by the presence of upstream repAB coding sequences. This apparent association of the group III $\operatorname{rep} C$ with similar rep $A B$ sequences may imply that the partition and replication systems have co-evolved. PCR-based studies to look at the variation between $\operatorname{rep} A B$ sequences amongst and between plasmids of known repC groups are under way to address this question.

The restriction fragment hybridizing to the group IV repC probe varied in size from 4.5 to $11 \mathrm{~kb}$, but the polymorphic sites cannot be located from this information because there is no internal EcoRI site in the group IV PCR products. The EcoRI restriction polymorphisms detected with the group I, III and IV probes again suggest that plasmid transfer has occurred. Identical hybridization patterns were found in a range of different chromosomal backgrounds, and in strains from different field sites. 


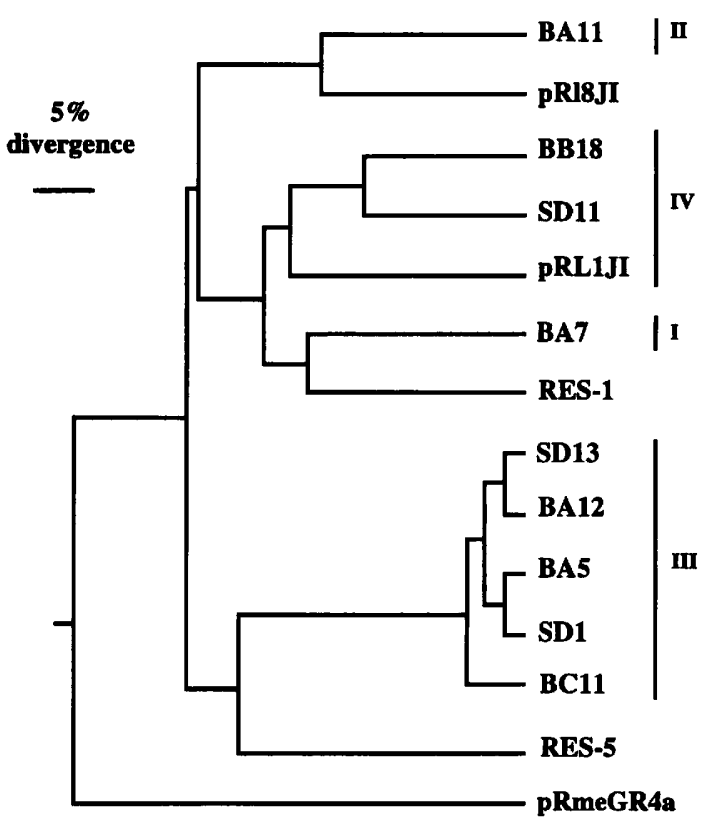

Fig. 3. UPGMA (unweighted pair group method with arithmetic mean) dendrogram showing the relationships between repC sequences revealed by PCR-RFLP analysis with eight endonucleases. repC sequence of pRmeGR4a from Sinorhizobium meliloti (Mercado-Blanco \& Olivares, 1993) was included by inferring its RFLP from the sequence available in the GenBank database (accession number X69105).
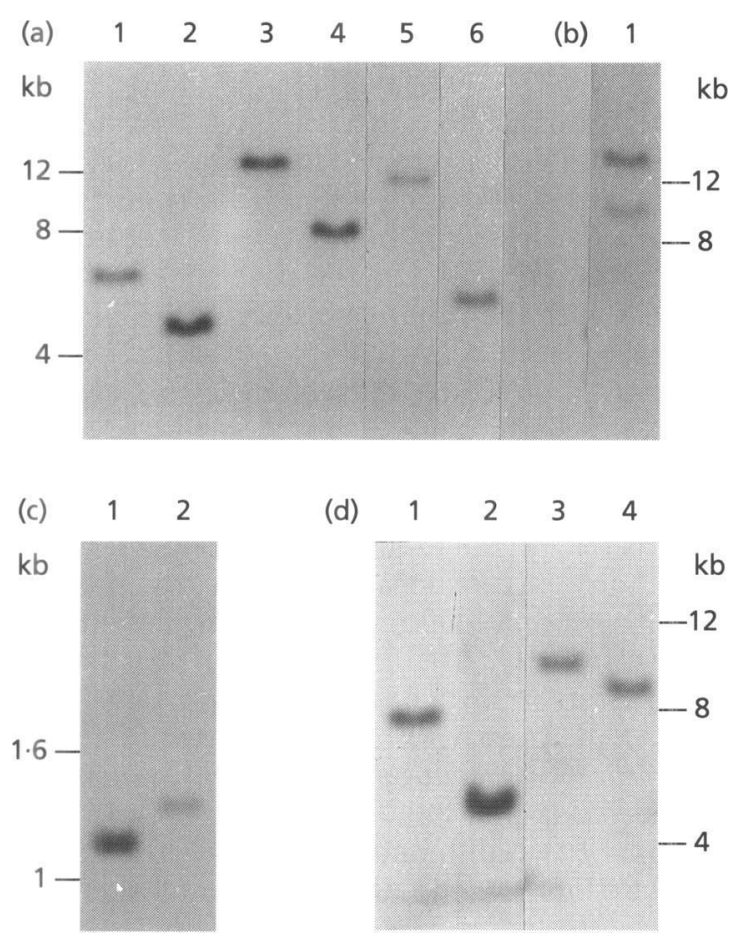

Fig. 4. EcoRI-digested total DNA from $R$. leguminosarum bv. viciae field isolates hybridized with: (a) repCl probe, lanes 1 to 6, strains BA7, BD13, BA12, SA6, BD3, RES-5; (b) repCll probe, lane 1, strain BA11; (c) repClll probe, lanes 1 and 2, strains SD13 and FIII-12; (d) repCIV probe, lanes 1 to 4, strains BA7, SD11, SC3, BC1.
The group II probe hybridized with two fragments $(14 \mathrm{~kb}$ and 9.8 or $7 \cdot 7 \mathrm{~kb}$ ) in all but three of the 23 positive strains, suggesting that two copies of this sequence were present in the majority of strains. RFLP analysis of group II PCR products showed that EcoRI does not cut the target sequence of any of the amplification products. Furthermore, the probe hybridized with two bands after total DNA was digested with BamHI, which also does not cut the probe sequence, strongly suggesting that there really are two copies of the group II $r e p C$ sequence. Only three field isolates, FIII-70, FIII-72 and FIII-37, have a single band hybridizing with the group II sequence $(14 \mathrm{~kb})$. Again it is not possible to say whether the polymorphisms are associated with variation within the replicator sequences or not.

\section{Localization of the repC sequences on different plasmids}

A more detailed investigation of the plasmid profiles was achieved by Southern analysis of Eckhardt gels with the four repC probes, and with a nodEFDABC probe to identify the symbiotic plasmid of each isolate (Downie et al., 1985). Fig. 1(b) shows typical hybridization results and Fig. 2 shows a schematic representation of the plasmid profiles and the hybridization patterns obtained with each of the five probes for all 51 isolates. The distribution of repC groups using this screen was the same as that described following probing of the EcoRIdigested genomic DNAs (Table 2). At least one repC sequence was present in each of the 51 isolates for which plasmid profiles were obtained, except isolates SA20 and RES-3. In all cases the $\operatorname{rep} C$ sequences were shown to be plasmid-associated. When repC sequences belonging to different groups were present in an isolate they were usually associated with different plasmids. In general each group-specific repC probe hybridized with only one plasmid in each isolate (see below).

There are eight profiles in Fig. 2 (profiles 1, 7 strain BB20, 9, 18, 19, 20, 22, 23) that have a single plasmid band highlighted by two different repC probes. One explanation for this is that each dual-hybridizing band represents a doublet of co-migrating but distinct plasmids, as documented for the smallest plasmid band of $R$. leguminosarum strain 3841 (Hirsch et al., 1980). This may be the case for some of the plasmid bands, for example the third-smallest band of SA1 (Fig. 1, lane 10) is more intense than the other plasmid bands of this isolate and may represent a doublet. This and other possible plasmid doublets are indicated as a thick line in Fig. 2. Where there is no obvious increase in band intensity it seems more likely that these bands represent dual-replicon plasmids (second-smallest band in profile $1,20,23$; third-smallest band in profile 7 strain BB20). Plasmids carrying multiple, compatible replication systems have been described for other plasmid systems (Lane \& Gardener; 1979, Danbara et al., 1980). Furthermore, cointegrate, dual-replicon plasmids that form and are stable in Agrobacterium are known (Hooykaas et al., 1980; Ooms et al., 1982). These are now known to form between mini-replicons carrying different repC 
genes (Paul Hooykaas, personal communication), and the Paracoccus versutus plasmid pTAV1 (Bartosik et al., 1995) has two functional replicator regions (GenBank accession numbers U42228 and U60522), both of which have repC genes related to those of $R$. leguminosarum.

\section{Genetic background and plasmid stability}

It is evident from Table 2 that plasmid groups and nod types are not distributed randomly across the different chromosomal classes. For example, the group III probe hybridized with plasmids in strains of all chromosome types, except those belonging to class a, regardless of their nodD-F pattern and their country of origin. This might suggest that group III plasmids cannot be transferred into the class a background, or that they cannot be maintained in it. To investigate this further, patch matings were made between BB18, which contains a group III pSym (Fig. 2), and strain P262SpSt, which has an a1-type chromosome and has been cured of its pSym (Table 1). Transconjugants resistant to spectinomycin and streptomycin were screened for symbiotic proficiency in plant nodulation trials (Geniaux \& Amarger, 1993). Transfer resulting in symbiotic proficiency was observed and group III repC sequences could be detected in antibiotic-resistant bacteria isolated from nodules by group-specific PCR. These sequences were rapidly and completely lost when bacteria isolated from the nodules were grown on laboratory media, the equivalent of nonselective conditions. These bacteria had also lost their ability to nodulate peas. Laguerre et al. (1992) noted that strains belonging to chromosomal plac12 type a carry two large $(\sim 450$ and $800-900 \mathrm{~kb})$ plasmids that have proven impossible to cure. These plasmids might influence the capacity of these strains to accommodate repC group III plasmids. They do not have repC genes that are closely related to group III, but it is conceivable that they express incompatibility through some other essential maintenance function such as partition. The possibility that repA and $r e p B$ gene products are involved in incompatibility is being investigated.

\section{Do the different repC groups correspond to incompatibility classes?}

Turner et al. (1996) proposed that the distinct repC groups identified in $R$. leguminosarum field isolates might correspond to different plasmid incompatibility classes. Plasmids are compatible if they can be comaintained by a host cell under non-selective conditions. The large size and cryptic nature of many of the plasmids carried by $R$. leguminosarum field isolates makes classical plasmid incompatibility studies difficult to undertake. However, the plasmid source of the partial repC sequence cloned from strain RSM2004 has been identified. The RSM2004 repC sequence clusters with group IV sequences, but is not amplified by the group IV-specific primer set (Turner et al., 1996). PCR primers were designed to amplify the RSM2004 repC sequence and these amplified a single product from RSM2004 and from a $1062 / \mathrm{pRL} 1 \mathrm{JI}$ transconjugant (gift of P. Hirsch,
Rothamsted, UK), but not from the parental 1062 strain. Thus the RSM2004 partial repC sequence belongs to plasmid pRL1JI. Plasmid pRL1JI has been shown to be incompatible with plasmids pRL3JI and pRL4JI identified in strains 306 and 309 respectively (Brewin et al., 1982). PCR analysis of strains 306 and 309 , and 1062/pRL3JI and 1062/pRL4JI transconjugants using the RSM 2004-specific primer set generated a single PCR product with all four strains. Sequencing of the PCR products obtained from strains RSM2004, 306 and 309 revealed that all three were identical to the published sequence for the RSM2004 clone (EMBL accession number Z69844).

The finding that the incompatible plasmids pRL1JI, pRL3JI and pRL4JI have identical partial repC sequences is consistent with the hypothesis that repC is an incompatibility determinant or is tightly linked to an incompatibility determinant. To assess the extent of incompatibility within and between repC groups $\mathrm{Sm}^{\mathrm{r}}$ field isolates were selected and then used in conjugation studies with RSM2004/pRL1JI::Tn5. Group-specific PCR analysis of two $\mathrm{Km}^{\mathrm{r}} \mathrm{Sm}^{\mathrm{r}}$ transconjugants of both SA6 and BB18 suggest that acquisition of pRL1JI : : Tn5 is associated with loss of the indigenous group IV sequence. Eckhardt analysis of these strains (not shown) indicated that the plasmid band corresponding to the indigenous group IV plasmid has been lost, although acquisition of a discrete band corresponding in size to pRL1JI::Tn5 was not always observed and plasmid rearrangements were also seen. As mentioned in the Introduction, such rearrangements are often associated with plasmid transfers.

The repC plasmid hybridization patterns for strains BB20 and RES-6, plasmid profiles 7 and 30 respectively, are unusual, because each contains two different plasmids that hybridize with the same probe (the group I and II probes respectively). In the case of $\mathrm{BB} 20$ one also hybridized with the group II probe. This plasmid band did not appear to be a doublet and could represent a cointegrate plasmid in which the group I repC is not active/dominant and does not contribute to incompatibility. Neither of the two group II plasmids of RES6 hybridized with any other repC probe. The PCR-RFLP data collected for the French isolates suggest that when two repC group II sequences are present in these strains the RFLP pattern is identical for both copies. PCR-RFLP analysis (HinfI, HaeIII, PstI and TaqI) of the product obtained from strain RES-6 using the group II primers gave a complex restriction pattern in which the sum of the restriction fragment bands was approximately twice that expected $(\sim 1 \cdot 1 \mathrm{~kb})$. The pattern appeared to be a composite of two different restriction patterns: that of the BA11 clone (group II) and that of the sequence previously cloned from RES-6 (data not shown). The RES-6 group II amplification product was cloned into pGEM-T (Promega) and clones with restriction patterns corresponding to each of these were selected, and sequenced. The sequence data support the RFLP data: one sequence was identical to the full-length sequence cloned from BA11, and the second was distinct and the 
same as the RES-6 clone (EMBL accession number Z69866).

This RES-6 sequence shows approximately $15 \%$ divergence from the other sequences that have been collected into group II, and it is possible that this is sufficient to make this replicon compatible with other group II sequences. Work is under way to address this question. An alternative explanation is that they are not compatible, but that one or both of the plasmids found carry a second functional replication system and it is this that enables their coexistence. The majority (158 out of 271) of all the bands identified in the plasmid profiles do not hybridize with any of the four repC probes used in this study, indicating that there must be a number of additional plasmid replication systems that are not detected by our probes. Even if such a replicator had an homologous repC, we might not have detected it because of the high sequence divergence found among repC genes: neither of the replicators found on pTAV1, for example, would be predicted to hybridize with, or be amplified by any of the probes used in this study under the conditions used.

The data presented in this paper generally support our hypothesis (Turner et al., 1996) that the repC sequence groups correspond to plasmid incompatibility groups. The apparent exceptions have possible explanations that are amenable to testing, and further study will reveal more about the evolutionary dynamics of this complex family of replicons.

\section{ACKNOWLEDGEMENTS}

This work was funded by the EU as part of BIOTECH contract BIO-CT92-370. We thank M. Bours for technical assistance and $\mathrm{P}$. Hirsch and $\mathrm{W}$. Lotz for providing strains.

\section{REFERENCES}

Baldani, J. I., Weaver, R. W., Hynes, M. F. \& Eardly, B. D. (1992). Utilization of carbon substrates, electrophoretic enzyme patterns, and symbiotic performance of plasmid-cured clover rhizobia. Appl Environ Microbiol 58, 2308-2314.

Bartosik, D., Baj, J. \& Wlodarczyk, M. (1995). Construction and preliminary characterization of mini-derivatives of a large ( $>107 \mathrm{~kb}$ ) cryptic plasmid of the sulfur bacterium Thiobacillus versutus. FEMS Microbiol Lett 129, 169-174.

Bergersen, F. J. (1961). The growth of Rhizobium in synthetic media. Aust J Biol Sci 14, 349-360.

Beringer, J. E. (1974). R factor transfer in Rhizobium leguminosarum. J Gen Microbiol 84, 188-198.

Brewin, N. J., Beringer, J. E., Buchanan-Wollaston, A. V., Johnston, A. W. B. \& Hirsch, P. R. (1980). Transfer of symbiotic genes with bacteriocinogenic plasmids in Rhizobium leguminosarum. J Gen Microbiol 116, 261-270.

Brewin, N. J., Wood, E. A., Johnston, A. W. B., Dibb, N. J. \& Hombrecher, G. (1982). Recombinant nodulation plasmids in Rbizobium leguminosarum. J Gen Microbiol 128, 1817-1827.

Brom, S., Garcia de los Santos, A., Girard, M. L., Davila, G., Palacios, R. \& Romero, D. (1991). High frequency rearrangements in Rhizobium leguminosarum bv. phaseoli plasmids. J Bacteriol $173,1344-1346$
Danbara, H., Timmis, J. K., Lurz, R. \& Timmis, K. N. (1980). Plasmid replication functions : two distinct segments of plasmid R1, RepA and RepD express incompatibility and a re capable of autonomous replication. J Bacteriol 144, 1126-1138.

Demezas, D. H., Reardon, T. B., Watson, J. M. \& Gibson, A. H. (1991). Genetic diversity among Rhizobium leguminosarum bv. trifolii strains revealed by allozyme and restriction fragment length polymorphism analyses. Appl Environ Microbiol 57, 3489-3495.

Djordjevic, M. A., Zurkowski, W. \& Rolfe, B. G. (1982). Plasmids and stability of symbiotic properties of Rhizobium trifolit. J Bacteriol 151, 560-568.

Downie, J. A., Knight, C. D., Johnston, A. W. B. \& Rossen, L. (1985). Identification of genes and gene products involved in the nodulation of peas by Rhizobium leguminosarum. Mol Gen Genet 198, 255-262.

Eckhardt, T. (1978). A rapid method for the identification of plasmid desoxyribonucleic acid in bacteria. Plasmid 1, 584-588.

Freiberg, C., Fellay, R., Bairoch, A., Broughton, W. J., Rosenthal, A. \& Perret, X. (1997). Molecular basis of symbiosis between R hizobium and legumes. Nature 387, 394-401.

Geniaux, E. \& Amarger, N. (1993). Diversity and stability of plasmid transfer in isolates from a single field population of Rhizobium leguminosarum bv. viciae. FEMS Microbiol Ecol 102, 251-260.

Hirsch, P. R. \& Spokes, J. D. (1994). Survival and dispersion of genetically modified rhizobia in the field and genetic interactions with native strains. FEMS Microbiol Ecol 15, 147-160.

Hirsch, P. R., Van Montagu, M., Johnston, A. W. B., Brewin, N. J. \& Schell, J. (1980). Physical identification of bacteriocinogenic, nodulation and other plasmids in strains of Rbizobium leguminosarum. J Gen Microbiol 120, 403-412.

Hooykaas, P. J. J., den Dulk-Ras, H., Ooms, G. \& Schilperoort, R. A. (1980). Interactions between octopine and nopaline plasmids in Agrobacterium tumefaciens. J Bacteriol 143, 1295-1306.

Hynes, M. F. \& McGregor, N. F. (1990). Two plasmids other than the nodulation plasmid are necessary for formation of nitrogenfixing nodules by Rhizobium leguminosarum. Mol Microbiol 4, 567-574.

Hynes, M. F., Brucksch, K. \& Priefer, U. (1988). Melanin production encoded by a cryptic plasmid in a Rhizobium leguminosarum strain. Arch Microbiol 150, 326-332.

Johnston, A. W. B., Beynon, J. L., Buchanan-Wollaston, A. V., Setchell, S. M., Hirsch, P. R. \& Beringer, J. E. (1978). High frequency transfer of nodulating ability between strains and species of Rhizobium. Nature 276, 634-636.

Jordan, D. C. (1984). Family III Rhizobiaceae. In Bergey's Manual of Systematic Bacteriology, vol. 1, pp. 235-244. Edited by N. R. Krieg \& J. G. Holt. Baltimore: Williams \& Wilkins.

Laguerre, G., Mazurier, S. I. \& Amarger, N. (1992). Plasmid profiles and restriction fragment length polymorphism of Rhizobium leguminosarum bv. viciae in field populations. FEMS Microbiol Ecol 101, 17-26.

Laguerre, G., Mavingui, P., Allard, M. R., Charnay, M. P., Louvrier, P., Mazurier, S. I., Rigottier-Gois, L. \& Amarger, N. (1996). Typing of rhizobia by PCR DNA fingerprinting and PCR-RFLP analysis of chromosomal and symbiotic gene regions: application to $R$. leguminosarum and its different biovars. Appl Environ Microbiol 62, 2029-2036.

Lane, D. \& Gardener, R. C. (1979). Second EcoRI fragment of F capable of self-replication. J Bacteriol 139, 141-151.

Mercado-Blanco, J. \& Olivares, J. (1993). Stability and trans- 
missibility of the cryptic plasmids of Rhizobium meliloti. Arch Microbiol 160, 477-485.

Nishiguchi, R., Takanami, M. \& Oka, A. (1987). Characterization and sequence determination of the replicator region in the hairyroot-inducing plasmid pRiA4b. Mol Gen Genet 206, 1-8.

Ooms, G., Regensburg-Tuink, T. J. G., Hofker, M. H., Hoekaema, A., Hooykaas, P. J. J. \& Schilperoort, R. A. (1982). Studies on the structure of cointegrates between octopine and nopaline $\mathrm{Ti}$ plasmids and their tumour-inducing properties. Plant Mol Biol 1, 265-276.

Prakash, R. K., Schilperoort, R. A. \& Nuti, M. P. (1981). Large plasmids of fast growing rhizobia : homology studies and location of structural nitrogen fixation (nif) genes. $J$ Bacteriol 145, 1129-1136.

Ramirez-Romero, M. A., Bustos, P., Girard, L., Rodriguez, O., Cevallos, M. A. \& Davila, G. (1997). Sequence, localisation and characteristics of the replicator region of the symbiotic plasmid of Rhizobium etli. Microbiology 143, 2825-2831.

Sambrook, J., Fritsch, E. F. \& Maniatis, T. (1989). Molecular Cloning: a Laboratory Manual, 2nd edn. Cold Spring Harbor, NY: Cold Spring Harbor Laboratory.

Schofield, P. R., Gibson, A. H., Dudman, W. F. \& Watson, J. M. (1987). Evidence for genetic exchange and recombination of Rhizobium symbiotic plasmids in a soil population. Appl Environ Microbiol 53, 2942-2947.

Selbitschka, W. \& Lotz, W. (1991). Instability of cryptic plasmids affects the symbiotic effectivity of Rhizobium leguminosarum bv. viciae. Mol Plant-Microbe Interact 6, 608-618.

Skorupska, A., Derylo, M. \& Golinowski, W. (1991). The region for exopolysaccharide synthesis in Rhizobium leguminosarum bv. trifolii is located on the non symbiotic plasmid. Acta Biochim Pol $38,423-435$.
Sneath, P. H. A. \& Sokal, R. R. (1973). Numerical Taxonomy. San Francisco: W. H. Freeman.

Soberon-Chavez, G., Noyera, R., Espin, G. \& Moreno, S. (1991). Formation of Rhizobium phaseoli symbiotic plasmids by genetic manipulation. Mol Microbiol 5, 909-916.

Sokal, R. R. \& Michener, C. D. (1958). A statistical method for evaluating systematic relationships. Univ Kansas Sci Bull 38, 1409-1438.

Tabata, S., Hooykaas, P. J. J. \& Oka, A. (1989). Sequence determination and characterization of the replicator region in the tumour-inducing plasmid pTiB6S3. J Bacteriol 171, 1665-1672.

Thurman, N. P., Lewis, D. M. \& Jones, G. (1985). The relationship of plasmid number to growth, acid tolerance, and symbiotic efficiency in isolates of Rhizobium trifolii. J Appl Bacteriol 58, $1-6$.

Turner, S. L. \& Young, J. P. W. (1995). The replicator region of the Rhizobium leguminosarum cryptic plasmid pRL8JI. FEMS Microbiol Lett 133, 53-58.

Turner, S. L., Rigottier-Gois, L., Power, R. S., Amarger, N. \& Young, J. P. W. (1996). Diversity of repC plasmid-replication sequences in Rhizobium leguminosarum. Microbiology 142, $1705-1713$.

Wheatcroft, R., McRae, D. G. \& Miller, R. W. (1990). Changes in the Rhizobium meliloti genome and the ability to detect supercoiled plasmids during bacteroid development. Mol PlantMicrobe Interact 3, 9-17.

Young, J. P. W. \& Wexler, M. (1988). Sym plasmid and chromosomal genotypes are correlated in field populations of $R$ hizobium leguminosarum. J Gen Microbiol 134, 2731-2739.

Received 19 August 1997; revised 3 November 1997; accepted 20 November 1997. 